\title{
RELATIONSHIP BETWEEN RED BLOOD CELL AND PLATELET INDICES IN IRON DEFICIENCY ANEMIA
}

\author{
Sahar Rabbani, Muhammad Farooq, Samina Naeem, Muhammad Abdul Naeem*, Nasir Uddin, Muhammad Zubair** \\ Combined Military Hospital Lahore/National University of Medical Sciences (NUMS) Pakistan, *Armed Forces Institute of Transfusion/National University of \\ Medical Sciences (NUMS) Rawalpindi Pakistan, ${ }^{* *}$ Shalamar Medical \& Dental College Lahore Pakistan
}

\begin{abstract}
Objective: To find out the correlation between the red blood cell and platelet indices in patients presenting with iron deficiency anemia at a tertiary care hospital of Pakistan.

Study Design: Cross-sectional study.

Place and Duration of Study: Department of Hematology, Combined Military Hospital Lahore, from Sep 2018 to Mar 2019. Methodology: The patients of age 1-70 years of either gender presenting with IDA were included in the study. The blood sample of patients were sent to laboratory to assess the red blood cell and platelet indices. SPSS-23 was used to analyze data.

Results: Two hundred and seven patients fulfilling the inclusion criteria were included in this study. The mean age was $25.6 \pm$ 17.8years. Correlation was weak and insignificant between haemoglobin and packed cell volume $\left(\mathrm{r}=-0.385^{* *}, p<0.01\right)$, haemoglobin and mean cell volume $\left(\mathrm{r}=-0.225^{* *}, p<0.01\right)$, packed cell volume and mean cell haemoglobin $\left(\mathrm{r}=0.263^{* *}, p<0.01\right), \&$ mean cell haemoglobin and mean platelet volume $\left(\mathrm{r}=0.143^{*}, p<0.05\right)$. Correlation was moderate and significant between platelet distribution width and mean platelet volume $\left(\mathrm{r}=0.511^{* *}\right)$ \& platelet distribution width and platelet large cell ratio $\left(0.502^{* *}, p<0.01\right)$. Correlation was strong between mean platelet volume and platelet large cell ratio $\left(\mathrm{r}=0.759^{* *}, p<0.01\right)$.

Conclusion: In conclusion, there was significant relation between red blood cell and platelets indices in iron deficiency anemia. Furthermore, haemoglobin and packed cell volume are weekly correlated, platelet distribution width and mean platelet volume are moderately correlated and mean platelet volume and platelet large cell ratio are strongly correlated.
\end{abstract}

Keywords: Iron deficiency anemia, Platelet indices, Red blood cells.

This is an Open Access article distributed under the terms of the Creative Commons Attribution License (http://creativecommons.org/licenses/by/4.0), which permits unrestricted use, distribution, and reproduction in any medium, provided the original work is properly cited.

\section{INTRODUCTION}

Iron deficiency anemia (IDA) is a global health problem affecting people of all age groups, being most prevalent in children, women and elderly where it complicates different underlying medical conditions. IDA is among the five leading causes of disability among humans. It's aetiology is multifactorial involving physiologic, pathologic, genetic and environmental causes $^{1}$. Anemia in elderly is associated with multiple comorbidities which makes it's diagnosis and management a challenge ${ }^{2}$. A worldwide wide survey in 2010 estimated that approximately 1.24 billion people are affected with iron deficiency anemia with variations in low and high income countries ${ }^{3}$. More than 500 million women of reproductive age group are affected by anemia globally which contributes to mortality and morbidity in pregnancy ${ }^{4,5}$.

Iron deficiency anemia adversely affects the growth, cognition, mortality and morbidity of children in Pakistan. According to a national survey $33.2 \%$ of children aged $>5$ years are iron deficient leading to

Correspondence: Dr Sahar Rabbani, Department of Haematology, Combined Military Hospital Lahore Pakistan

Received: 25 Feb 2020; revised received: 10 Jun 2020; accepted: 15 Jun 2020 stunted growth ${ }^{6}$. In Pakistan several factors contribute to IDA which include poverty, illiteracy, malnutrition and lack of proper policies and infrastructure. A multipronged approach is required to combat all these issues in women and children which are the most affected ${ }^{7}$. Iron is an important micro nutrient whose deficiency in pregnancy is prevalent in Pakistani women living in urban areas up to $29-50 \%$. It is most common during second trimester8.

The causes of IDA include increase in red blood cell destruction or reduction in red cell production, blood loss due to injury or trauma and alterations of platelet count ${ }^{9}$. Moderate IDA is often associated with thrombocytosis and severe IDA, when haemoglobin level is $<7 \mathrm{~g} / \mathrm{dl}$ mostly accompanies thrombocytopenia ${ }^{10}$. In different studies conducted in mice showed that iron deficiency contributed to increased erythropoietin activity leading to secondary activation of megakaryopoiesis. This observation lead clinicians to notice that in humans iron deficiency anemia is associated with normal, high or rarely low platelet count as compared to beta thalassemia where there is no such change in spite of increased EPO activity. Therefore, estimating the changes in platelet and red blood cell indices is important in IDA. 
Hence the present study was conducted to find out the correlation between the red blood cell and platelet indices in patients presenting with iron deficiency anemia at a tertiary care hospital of Pakistan.

\section{METHODOLOGY}

It was a cross-sectional conducted at the department of hematology of Combined Military Hospital Lahore, from Sept 2018 to Mar 2019. The sample size was estimated using online sample size for correlation calculator by taking statistics for correlation between Haemoglobin and platelet count as $r=-0.249$, power of test as $80 \%$ and $95 \%$ confidence level in IDA patients, the calculated sample size came out as 204. However, we enrolled 217 IDA patients using non-probability consecutive sampling technique. The patients of age 1-70 years of either gender presenting with IDA were included in the study. Patients with chronic disease, comorbid (hypertension, diabetes mellitus, obesity \& ischemic heart disease) \& renal dysfunctions were excluded from the study.

The ethical review committee approval (Number 132/2019) was sought before the conduct of study. Informed written and verbal consent was taken from all the patients. Information regarding age and gender were obtained from all the patients. The blood sample of patients were sent to laboratory to assess the hemoglobin level $(\mathrm{g} / \mathrm{dl})$, hematocrit (HCT\%), Mean cell volume (MCV fL), mean cell hemoglobin (MCH pg), red celldistribution width (RDW fL), Platelet count (PLT $\times 1000 / \mathrm{uL}$ ), Platelet distribution width (PDW fL), Mean platelet volume (MPV fL) \& Platelet larger cell ratio (PLCR\%).

SPSS-23 was used to analyze data. Mean \& SD was reported for all continuous variables whereas frequencies \& percentages were computed for all qualitative variables. Pearson correlation was applied to see the relationship between red blood cell \& platelet indices. A $p \leq 0.05$ was taken as statistically significant.

\section{RESULTS}

Two hundred and seventh patients fulfilling the inclusion criteria were included in this study. The mean age was $25.6 \pm 17.8$ years. Majority of the patients were adults (38.7\%) followed by children (22.6\%) (table-I). Out 217 IDA patients, most of them were females $(51.6 \%)$ as compared to males $(48.4 \%)$.

Out of 217 IDA patients, majority of the patients had $\mathrm{Hb}<10 \mathrm{~g} / \mathrm{dl}(63.6 \%)$, low Hct\% (91.2\%), normal RDW fL $(80.2 \%)$, normal platelet count $(\times 1000 / \mathrm{uL})$ $(71.9 \%)$, normal PDW fL (84.3\%), normal MPV fL (88\%)
\& normal PLCR\% (90.8\%) whereas all the patients had low MCV fL $(100 \%)$ as shown in table-II.

Table-I: Frequency distribution of age.

\begin{tabular}{|c|c|}
\hline Variables & n ( $\%)$ \\
\hline \multicolumn{2}{|l|}{ Age Groups } \\
\hline Children (1-12 yrs) & $49(22.6)$ \\
\hline Teenagers (13-19 yrs) & $34(15.7)$ \\
\hline Adults (20-35 yrs) & $84(38.7)$ \\
\hline Older adults (36-55) & $35(16.1)$ \\
\hline Elders ( $>55$ years) & $15(6.9)$ \\
\hline Mean \pm SD & $25.6 \pm 17.8$ \\
\hline \multicolumn{2}{|c|}{ Table-II: Hematologic parameters. } \\
\hline Variable & n (\%) \\
\hline \multicolumn{2}{|l|}{ Haemoglobin (g/dl) } \\
\hline$<10 \mathrm{~g} / \mathrm{dl}$ & $138(63.6)$ \\
\hline $10-13.5 \mathrm{~g} / \mathrm{dl}$ & $79(36.4)$ \\
\hline \multicolumn{2}{|c|}{ Haematocrit or packed cell volume $(\%)$} \\
\hline Normal & $19(8.8)$ \\
\hline Low & $198(91.2)$ \\
\hline \multicolumn{2}{|l|}{ Mean cell volume (fL) } \\
\hline Normal & - \\
\hline Low & $217(100)$ \\
\hline \multicolumn{2}{|c|}{ Mean cell haemoglobin (pg) } \\
\hline Normal & $9(4.1)$ \\
\hline Low & $208(95.9)$ \\
\hline \multicolumn{2}{|c|}{ Red cell distribution width (fL) } \\
\hline Normal & $174(80.2)$ \\
\hline Low & $43(19.8)$ \\
\hline \multicolumn{2}{|l|}{ Platelets (x1000/ul) } \\
\hline Normal & $156(71.9)$ \\
\hline Low & $3(1.4)$ \\
\hline High & $58(26.7)$ \\
\hline \multicolumn{2}{|c|}{ Platelet distribution width (fL) } \\
\hline Normal & $183(84.3)$ \\
\hline Low & $23(10.6)$ \\
\hline High & $11(5.1)$ \\
\hline \multicolumn{2}{|c|}{ Mean platelet volume (fL) } \\
\hline Normal & $191(88.0)$ \\
\hline Low & $24(11.1)$ \\
\hline High & $2(0.9)$ \\
\hline \multicolumn{2}{|c|}{ Platelet large cell ratio (\%) } \\
\hline Normal & $197(90.8)$ \\
\hline Low & $18(8.3)$ \\
\hline High & $2(0.9)$ \\
\hline
\end{tabular}

Correlation was weak and significant between $\mathrm{Hb} \& \mathrm{PCV}\left(\mathrm{r}=-0.385^{* *}, p<0.01\right), \mathrm{Hb} \& \mathrm{MCH}\left(\mathrm{r}=-0.225^{* *}\right.$, $p<0.01), \mathrm{PCV} \& \mathrm{MCH}\left(\mathrm{r}=0.263^{* *}, p<0.01\right)$, \& $\mathrm{MCH} \&$ MPV $\left(\mathrm{r}=0.143^{*} p<0.05\right)$. Correlation was moderate and significant between PDW \& MPV $\left(\mathrm{r}=0.511^{* *}\right.$, $p<0.01) \&$ PDW \& PLCR $\left(0.502^{* *}, p<0.01\right)$. Correlation was strong between MPV \& PLCR $\left(\mathrm{r}=0.759^{* *}, p<0.01\right)$ (table-III). 
Table-III: Pearson's correlation between red blood cell \& platelet indices

\begin{tabular}{|c|c|c|c|c|c|c|c|c|}
\hline & $\mathbf{H b}$ & $\begin{array}{c}\text { Packed } \\
\text { cell } \\
\text { volume }\end{array}$ & $\begin{array}{c}\text { Mean cell } \\
\text { haemoglobin }\end{array}$ & $\begin{array}{c}\text { Red cell } \\
\text { distribution } \\
\text { width }\end{array}$ & Platelet & $\begin{array}{c}\text { Platelet } \\
\text { distribution } \\
\text { width }\end{array}$ & $\begin{array}{c}\text { Mean } \\
\text { platelet } \\
\text { volume }\end{array}$ & $\begin{array}{c}\text { Platelet } \\
\text { large cell } \\
\text { ratio }\end{array}$ \\
\hline Haemoglobin & 1 & $-0.385^{* *}$ & $-0.225^{* *}$ & -0.113 & -0.092 & -0.003 & -0.072 & -0.042 \\
\hline Packed cell volume & $-0.385^{* *}$ & 1 & $0.263^{* *}$ & -0.010 & 0.047 & 0.041 & -0.041 & -0.018 \\
\hline $\begin{array}{l}\text { Mean cell } \\
\text { haemogloin }\end{array}$ & $-0.225^{* *}$ & $0.263^{* *}$ & 1 & 0.045 & 0.130 & -0.041 & $-0.143^{*}$ & -0.099 \\
\hline $\begin{array}{l}\text { Red cell distribution } \\
\text { width }\end{array}$ & -0.113 & -0.010 & 0.045 & 1 & 0.006 & -0.018 & -0.038 & -0.036 \\
\hline Platelet count & -0.092 & 0.047 & 0.130 & 0.006 & 1 & 0.026 & 0.086 & 0.050 \\
\hline $\begin{array}{l}\text { Platelet distribution } \\
\text { width }\end{array}$ & -0.003 & 0.041 & -0.041 & -0.018 & 0.026 & 1 & $0.511^{* *}$ & $0.502^{* *}$ \\
\hline Mean platelet volume & -0.072 & -0.041 & $-0.143^{*}$ & -0.038 & 0.086 & $0.511^{* *}$ & 1 & $0.759 * *$ \\
\hline $\begin{array}{l}\text { Platelet large cell } \\
\text { ratio }\end{array}$ & -0.042 & -0.018 & -0.099 & -0.036 & 0.050 & $0.502^{* *}$ & $0.759 * *$ & 1 \\
\hline
\end{tabular}

\section{DISCUSSION}

Around the globe, iron deficiency anemia is the most prevalent disease. The biochemical markers are variable among population. Complete blood count is therefore most significant test to rule out other anemias. Keeping this biochemical variation in view, the present study is conducted to ascertain correlation among different hematological markers in patients lacking serum ferritin. According to sociodemographic variables of this study are similar to study conducted in China; however, the participants enrolled in the study had mean age of 52 years ${ }^{11,12}$. On contrary, Kadikoylu et al and Park et al conducted study among female population only ${ }^{12,13}$. There is disagreement between findings of platelet count. The results of our study showed that $71.9 \%$ has normal platelet count while $26.7 \%$ had high platelet count $(58 \times 1000 /$ ul $)$ whereas other study showed normal platelet count $(400 \times 1000 / u l)^{10}$.

Recent studies reported that IDA can be associated with either thrombocytopenia or thrombocytosis. The results of our study are similar with the study of Yung et al and Kadikoylu et al where it was found that there exists a significant difference between IDA and platelet count. It was statistically significant between IDA and thrombocytosis and normal platelet count $(p<0.01)^{13,14}$. A study showed mean red cell distribution width in IDA pregnant women $12.83 \pm 1.03 \%$ in contrast with our study there was a negative correlation between $\mathrm{Hb}$ and $\mathrm{RDW}$ but a negative correlation between haemoglobin level and platelet count i.e. 0.09215 .

In a Turkish study ${ }^{16}$ and a study conducted by Dan et al ${ }^{18}, \mathrm{MPV}$ and Platelet count showed positive correlation similar to present findings ${ }^{12}$. In another study, Cho et al assessed MPV/platelet ratio in IDA group. The results reported are same with slight fluct- uation in numbers. This provides great support to our findings. There was reported thrombocytosis that is quite comparable with our findings and subjects showed less MPV/platelet count ratio $(p<0.001)$ in addition, ROC curve analysis of MPV/platelet count ratio showed $73 \%$ sensitivity and $80 \%$ specificity $79.6 \%$ at a cut-off level of 0.031812 .

The results of our study is also comparable with Semmelrock et al study that reported there is strong evidence of statistical relation of IDA and red blood cell parameters. Supporting these results, a study tested 917 blood donors suffering from IDA. The results showed that hemoglobin was impaired in $17 \%$ females which are highly variable as compare to our study ${ }^{17}$. Another study supporting the statement reported that reticulocyte count is directly proportional with haemoglobin, mean corpuscular volume, mean corpuscular haemoglobin ${ }^{18}$. A correlational study among PCT, RDW, MPV, MCV, HCT and PDW was carried out. The study showed no correlation between platelet crit and hematocrit. Moreover MCV and MPV also had not correlation between them. However, on the contrary, PDW and RDW were found significantly correlated with each other ${ }^{19}$.

\section{CONCLUSION}

In conclusion, there was significant relation between red blood cells and platelets indices in iron deficiency anemia. Furthermore, haemoglobin and haematocrit are weekly correlated, platelet distribution width \& mean platelet volume are moderately correlated and mean platelet volume and platelet large cell ratio are strongly correlated. There is immense literature available yet no strategies to treatment planning are devised. Platelet indices and red cell parameters have great impact upon quality of life. If better treatment strategies are devised, there will be a great reduction in 
morbidity rate and patient's quality of life can be enhanced. There is a need of proper screening and monitoring of the patients presenting with IDA to avoid anemia and to improve health status and quality of life in these patients.

\section{CONFLICT OF INTEREST}

This study has no conflict of interest to be declared by any author.

\section{REFERENCES}

1. Cappellini MD, Musallam KM, Taher AT. Iron deficiency anemia revisited. J Intl Med 2020; 287(2): 153-70.

2. Stauder R, Valent P. Anemia at older age: Etiologies, clinical implications and management. Blood 2018; 131(5): 505-14.

3. Camaschella C. Iron deficiency, iron metabolism and it's disorders. Blood 2019; 133(1): 30-39.

4. Jamnok J, Sanchaisuriya K, Sanchaisuriya P, Fucharoen G, Fucharoen S, Ahmed F. Factors associated with anemia and iron deficiency among women of reproductive age in Northeast Thailand: a cross-sectional study. BMC Public Health 2020; 102(20): 1-8.

5. Mawani M, Ali AS, Bano G. Iron deficiency anemia among women of reproductive age, an important public health problem: situation analysis. Reprod Syst Sex Disord 2016; 5(3): 1-6.

6. Habib MA, Black K, Soofi SB, Hussain I, Bhatti Z, Bhutta ZA, Greenow CR. Prevalence and predictors of iron deficiency anemia in children under five years of age in Pakistan, a secondary analysis of national nutrition survey data 2011-2012. PLoS One 2016; 11(5): 1-13.

7. Latif M, Ayaz SB, Manzoor M, Ishaq M. Frequency and severity of anemia in children less than 15 years of age at Gwadar development authority hospital, Gwadar, Baluchistan. Pak Armed Forces Med J 2018; 68(5): 1088-92.

8. Shams S, Ahmad Z, Wadood A. Prevalence of iron deficiency anemia in pregnant women of district Mardan, Pakistan. J Preg Child Health 2017; 4(6): 1-4.

9. Jadhav SU, Khaparde S. Study of the red cell indices, hemogram and platelet variations in anaemic. Int J Res Med Sci 2017; 5(4): 1582-88.

10. Park MJ, Park PW, Seo YH, Kim KH, Park SH, Jeong JH, et al. The relationship between iron parameters and platelet parameters in women with iron deficiency anemia and thrombocytosis. Platelets 2013; 24(5): 348-51.

11. Morris VK, Spraker HL, Howard SC, Ware RE, Reiss UM. Severe thrombocytopenia with iron deficiency anemia. Pediatr Hematol Oncol 2010; 27(5): 413-19.

12. Cho SY, Yang JJ, Suh JT, Lee WI, Lee HJ. Mean platelet volume/ platelet count ratio in anemia. Platelets 2013; 24(3): 244-45.

13. Kadikoylu G, Yavasoglu I, Bolaman Z, Senturk T. Platelet parameters in women with iron deficiency anemia. J Natl Med Assoc 2006; 98(3): 398-402.

14. Yung KC, Zhang ZW, Yu WJ, Qiu JF, Xu CW, He CL, et al. Preliminary investigation about the expression of tubulin in platelets from patients with iron deficiency anemia and thrombocytosis. Hematol 2018; 23(8): 549-57.

15. Sarah B, Sheikh K, Shah T. Red cell distribution width is early marker for detection of iron deficiency anemia during pregnancy. J Liaquat Uni Med Health Sci 2018; 17(3): 165-69.

16. Dan K. Thrombocytosis in iron deficiency anemia. Intern Med 2005; 44(10): 1025-26.

17. Semmelrock M, Raggam R, Amrein $K$, Avian A, Schallmoser $K$, Lanzer G, et al. Reticulocyte hemoglobin content allows early and reliable detection of functional iron deficiency in blood donors. Clin Chim Acta 2012; 413(7-8): 678-82.

18. Karagülle M, Gündüz E, Mutlu FŞ, Akay MO. Clinical significance of reticulocyte hemoglobin content in the diagnosis of iron deficiency anemia. Turkish J Hematol 2013; 30(2): 153.

19. Wiwanitkit V. Plateletcrit, mean platelet volume, platelet distribution width: its expected values and correlation with parallel red blood cell parameters. Clin Appl thrombosis / hemostasis 2004; 10(2): 175-78. 